\title{
MANAGING TALENTED EMPLOYEES
}

\section{ROBERT BALCERZYK, ${ }^{1}$ DOROTA BALCERZYK ${ }^{2}$}

\author{
General Tadeusz Kościuszko Military Academy of Land Forces in Wrocław, POLAND \\ 1 e-mail: robert.balcerzyk@awl.edu.pl \\ 2 e-mail: dorota.balcerzyk@awl.edu.pl
}

RECEIVED
ACCEPTED
JEL
CLASSIFICATION

KEYWORDS

ABSTRACT
18 January 2018

2 September 2018

J24, M12, M54, 015

talent, talent management, talented people

The main goal of the article is to present the results of research on the preparation of managers to "lead" talented people. The conducted research was of a pilot nature. In the first part of the article, several most popular definitions of talent are quoted. Then, the essence of "talent management" is provided. This is followed by the presentation of the "talent management" model concept. Based on the opinions of the respondents, the actions taken in practice towards talented people as well as diagnosed causes of fluctuation of talented people are described. The assessment of the degree of preparation of managers for dealing with talented people is made. The factors determining the functioning of "talent management" programs are shown. Afterwards, behaviors shaping the image of an employee as a professional or expert are presented. The analysis of research results allows for formulating conclusions that can be used in the design of "talent management" programs.

\section{Introduction}

The globalization of the economy has made knowledge the driving force behind financial, economic and social transformations. Man is the source of this knowledge, while employees are understood as human capital. They represent the added value of any organization. In today's economy, the competitive advantage is not built on 
the reduction of production costs, but on the purposeful and effective construction of intellectual capital. Its values include first and foremost knowledge and information.

The development of civilization is associated with change in all areas of society. This increases the complexity of the environment of operating organizations. The environment is (and is becoming more and more) turbulent and stormy. In such conditions, strategic management, knowledge management and talent management gained special significance for the functioning of an organization. Particular attention should be paid to the approach to the most valuable resource available to any organization, i.e. people.

The development of employee competencies has become the key activity of the managerial staff. Managers recognize the importance of talents for the development and operation of the organization. Moreover, the concept of talents was popularized at the end of the last century. The development of modern technologies has caused that the demand for employee talents exceeds their supply. As a result, the employee talents market has become the most competitive since the 1990s (Jabłoński, 2015, p. 35). It has been realized that the number of talents is limited.

\section{The essence of talent management}

There are numerous definitions of the term "talent" in the literature on management studies. The expressions such as "key employees", "employees with high development potential" and "employees with above-average results" are frequently used in scientific studies as regards talented persons.

The notion of "talent" derives from the Greek word talanton, which meant the unbearable burden for one person (Chełpa, 2015, p. 28).

According to L.A. Berger and R.B. Berger, talented people demonstrate higher than average achievements, inspire others to achieve above-average results, understand the key competences and values of the organization. Losing them reduces organizational growth because of their disproportionate impact on the organization's current and future performance (Ingram, 2011, p.14).

A. Pocztowski, on the other hand, believes that a talent is an individual who is guided by an internal goal, unchanged over a longer period, at the same time bringing his/her own goal to the organization (Pocztowski, 2011, p. 36).

Talent management can be treated as knowledge management, the skills of each employee occupying a specific position and contributing to the development of the organization. The art of management consists in clear definition of the company's strategy and needs and proper identification and utilization of these resources for the benefit of the organization and the employee (Antczak, 2010, p. 149). The art of talent management consists in the fact that the lack of patterns means that there are no established directions for the development in this field (Ingram, 2011, pp. 22-23). All this causes that talent management is evolving (drifting), however the results of this drift are impossible to specify. The main reasons for this are the struggle for a competitive advantage and the war for talents.

Human resources management, due to its nature, cannot be schematized (Pocztowski, 2008, p. 48). Therefore, talented people (as a rare good) elude classification and pose a problem and challenge to the personnel function. People, intellectual capital and talents are perceived as success factors in the organizational strategy.

Numerous models of talent management can be found in the literature on management. One of them is the model by T. Listwan (Figure 1). Its simplicity gives it special meaning. 


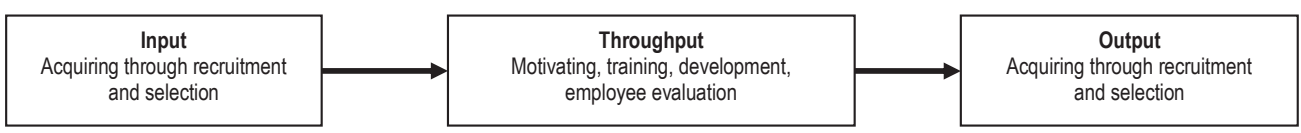

Figure 1. Talent management model by T. Listwan

Source: Listwan (2005), p. 22.

It builds on the classic concept of human resources management functions. The first stage is input. Acquiring talented people through appropriately designed recruitment and selection plays an important role here. The next step is throughput. These are the actions of managers focused on the professional development of talented people through training and up-skilling and the proper implementation of the human resource management sub-function, i.e. the employee evaluation. All this serves the right stimulation to motivate talents. The final stage is the output of the organization.

In the recent past, people saw companies as a source of livelihood. Today the situation is slightly different. It is companies that seek people (talented workers).

In such conditions, the "talent management" programs gain significance. They focus on the recruitment of talented people and professional development. Their task is also to create such conditions and work atmosphere to keep the most valuable employees. The result of such actions is the effective use of the talented persons' abilities in order to develop the company and implement its strategy.

\section{Methods and charracteristics of the research sample}

The following research methods were used in the studies presented in this article:

- the critical literature review method (literature in the field of talent management, employee development, management of knowledge),

- participant observation method (related to running one's own business),

- the analysis of secondary sources (studies of similar scope),

- diagnostic survey with company employees related to sub-functions of personnel management.

Triangulation of research methods was used in order to authenticate the research. This allowed to obtain a broader context of the studied phenomenon and ensured a higher quality of the conducted research. Differentiation of methods was aimed at obtaining consistency of the empirical basis for inference. The diagnostic survey method was adopted as the leading (main) method in the research work, while others were used as ancillary (supplementary) ones.

The study involved students of three universities in the Lower Silesian Voivodeship. They were students of parttime studies. In total, 327 people were examined. The vast majority of respondents were women. The breakdown of respondents by gender is shown in Figure 2 .

Most of the respondents (56\%) were young people aged $19-24$. About $31 \%$ of respondents were students aged $25-35$. Persons over 40 years of age constituted only $6 \%$ of the research group. The fact that young people take up learning at universities proves that they are aware of the fact that intellectual capital is an added value not only to an organization but also to an individual. When they start learning, they are aware of their competency gaps 
in knowledge or skills. They are at the beginning of their professional career where the field of exploration and the finalization of the choice of profession have been narrowed down. Figure 3 displays the age of respondents.

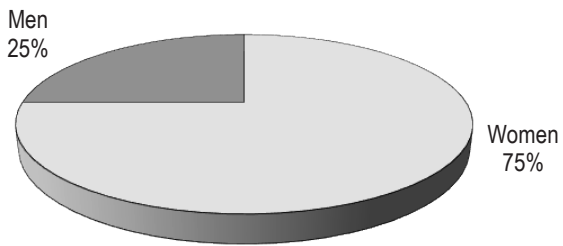

Figure 2. Gender breakdown of the study group

Source: own study.

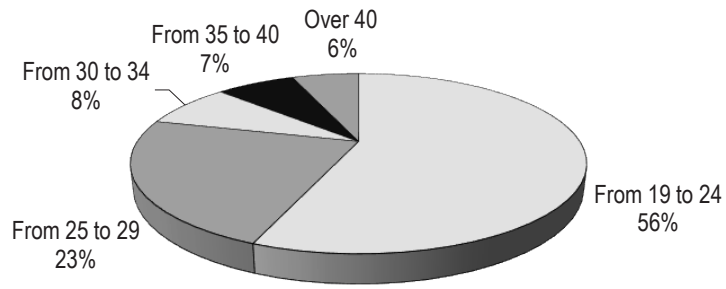

Figure 3. Study group by age

Source: own study.

The vast majority of the surveyed group is employees of large companies employing over 100 workers (38.5\%). About $15.9 \%$ of respondents worked in companies employing from 21 to 50 people, and $14.1 \%$ of respondents were employees of companies with from 51 to 100 workers. The employment of respondents by to the size of the company is shown in Figure 4.

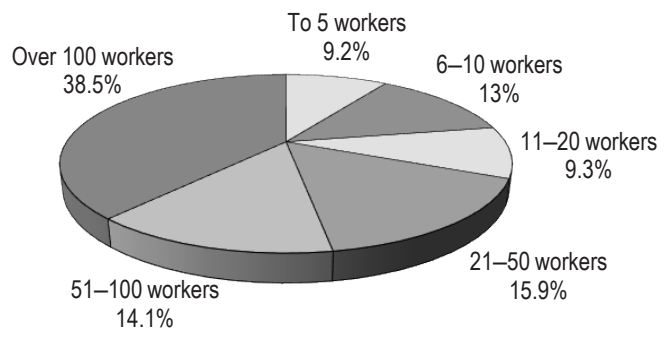

Figure 4. Employment of workers by company size

Source: own study. 
The main research tool was a diagnostic survey using a questionnaire. The questionnaire consisted of twenty closed and two open questions. In the questionnaire, the respondents, i.e. the people surveyed, were distinguished by gender, age and by the size of a company (as a place of employment). The main purpose of the survey was to collect data on the studied reality regarding the issues of talent management and the functioning of development programs targeted at employees. The questionnaire was divided into three parts. The first part concerned talented people, the second part was closely related to the "talent management" programs, and the last one was a statistical part. The use of a highly categorized questionnaire allowed for the transparent arrangement of responses in tabular summaries as a relatively simple and direct way to collect data and information, as well as easy to further statistical processing.

\section{Conditions of functioning of talented persons}

The research attempted to define what diagnosing an employee as a "talent" means in practice. Respondents were asked about the opinions, and their responses are presented in Figure 5.

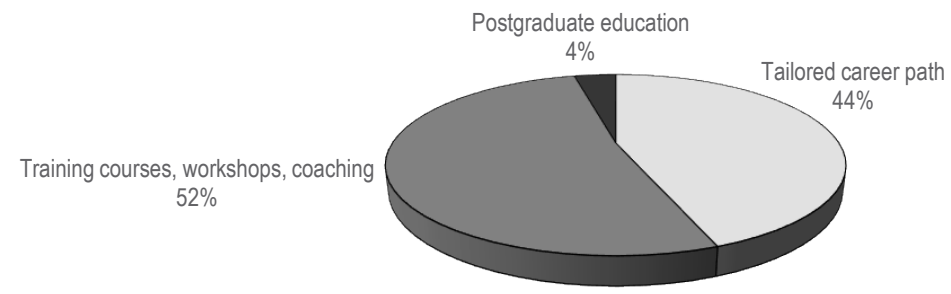

Figure 5. Actions taken towards people diagnosed as "talents" in respondents' opinion

Source: own study.

According to the surveyed, in practice, diagnosing an employee as "talent" means additional training, workshops, coaching, as stated by more than $52 \%$ of the respondents. When designing such activities, it should be remembered that adults are a specific training group. Their expectations regarding the progress of the training and the trainees themselves are high. In carrying out such projects, modern methods and techniques of training and professional development should be applied. It is said that such trainings should be "tailored", taking account of expectations of individual workers. The trainings implemented should correspond to the development direction of a particular employee or his/her motivation.

A lower number of the respondents (44\%) state that defining an employee as a talented person means an individual career path. Defining an employee as a "talent" is a very important premise that should be linked to aftereffect plans. The career path should, however, be subject to control in order to verify the activities carried out and, if necessary, allow for possible changes and corrections. It must be remembered that employee displacement plans have to be correlated with employee training and professional development plans.

Only $4 \%$ of students claim that this diagnosis means sending for postgraduate studies, which confirms the specifics of adults as a training group. 
The phenomenon of the so-called "wars for talents" is visible in the functioning of modern organizations. Managers should treat talented employees' leave as a phenomenon extremely unfavorable for the development and survival of the organization. The studies revealed the reasons why talented people resign from the work, as is shown in Figure 6.

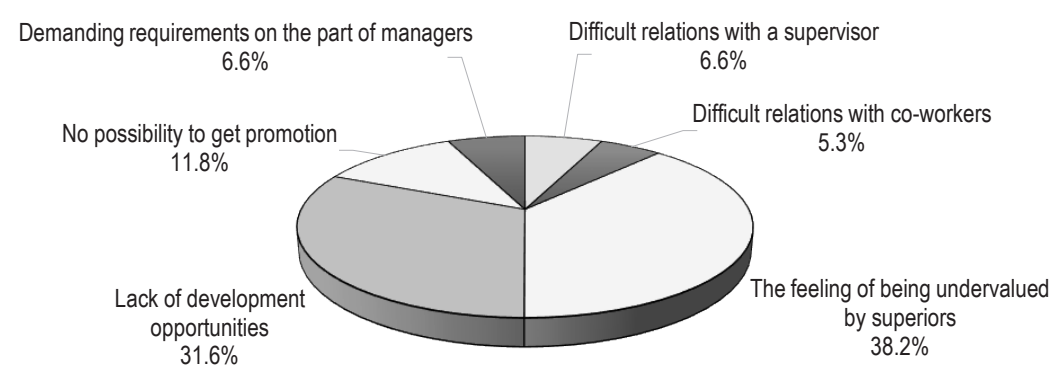

Figulf $\boldsymbol{G}$. Respondents' opinions on the reasons why talented people resign from work

Source: own study.

A significant part of the respondents (38.2\%) blame superiors for talented employee leaves. They are accused of undervaluing "talented people". About $31.6 \%$ indicated that the reason for leaving the company was the lack of development opportunities. This confirms the fact that superiors do not create a good climate for the use of "talents" and that they do not perceive them as the intellectual capital of the organization. They do not see them as the most valuable "resource" available to an organization, i.e. people. About $12 \%$ of respondents believe that the reason for leaving the company is the lack of promotion prospects. Such answers are a kind of surprise since the vast majority of respondents are employed in large companies with more than 100 staff. This points to the lack of responsibility of managers and human resources departments, or their ineptitude. They do not design the career trajectories for employees, which is what talented people expect.

Less important reasons for talented people's leave are difficult relations with the supervisor (6.6\%), excessive management requirements $(6.6 \%)$, difficult relations with co-workers $(5.3 \%)$. These are problems that practically all organizations face and they are inevitable. What deserves attention, however, is that no man has found that difficult relationships with co-workers may be the reason for giving up work. Respondents working in smaller service companies with up to 20 employees were also of the same opinion. Smaller organizations probably have friendly relations between colleagues, and the work itself is a pleasure. It should be noted that a friendly atmosphere, a good climate of cooperation and trust lead to better work efficiency.

Respondents aged 30-40 are of another opinion. Their opinions are presented in Figure. 7.

The vast majority of young employees indicate lack of development opportunities (36.8\%) and lack of promotion prospects (26.3\%) as factors decisive for the leave of "talented people". These people are at an early stage of their professional career. Their expectations towards employers are crystallized. Lastly, they want to develop and acquire new levels of professional competence. In the end, they want to satisfy their own ambitions. Therefore, the selection of the management staff is of particular importance. Managers should be able to scan the organization's 
surroundings in search of talented employees. The information obtained should be provided to superiors and human resources departments. They should also act as spokesmen for workers.

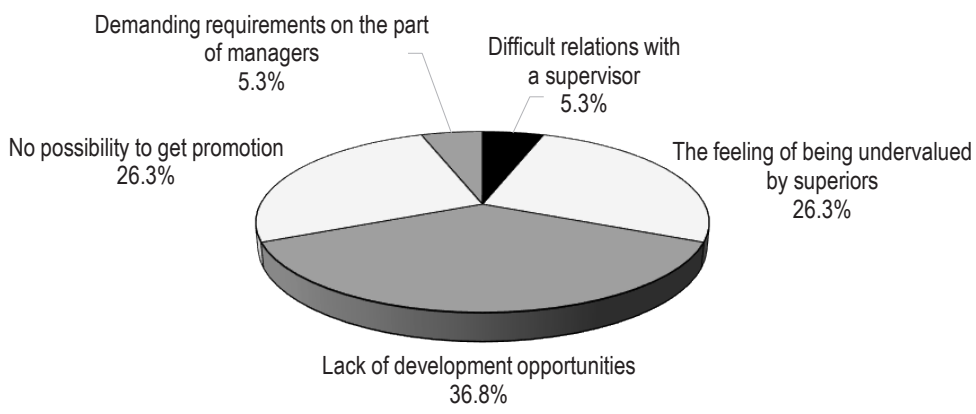

Figure 7. Respondents' opinions on the reasons why talented people resign from work Respondents aged 30-40)

Source: own study.

The respondents' opinion regarding the preparation of managers for individual employee management is presented in Figure 8.

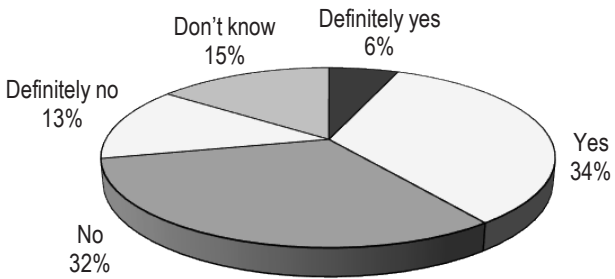

Figure 8. Assessment of managers' preparation for individual employee management

Source: own study.

About $40 \%$ of respondents believe (by stating yes or definitely yes) that managers are prepared for individual employee management, regular meetings, feedback, progress monitoring, as well as taking on the role of a mentor. It is a difficult task and requires a lot of experience from the manager. Distribution of tasks and their differentiation depending on the potential of workers are of great significance. Talented people should be assigned tasks that are more difficult, more complicated and forcing creativity. The increase in employee competence potential is also affected by job rotation and change of areas of activity. Such actions taken by the manager give the opportunity to check the talented person in practice. The period after selecting talented people is one of the most difficult stages. Then, the managers responsible for their development are assigned to employees. The research results, where $45 \%$ of respondents claim that managers in their organization are not ready for individual employee management 
testify that this is a complicated task. Therefore, this period is the hardest test for managers over the entire talent management process.

In the next stage of the research, an attempt was made to identify the factors determining the functioning of "talent management" programs in the organization. The results are shown in Figure 9.

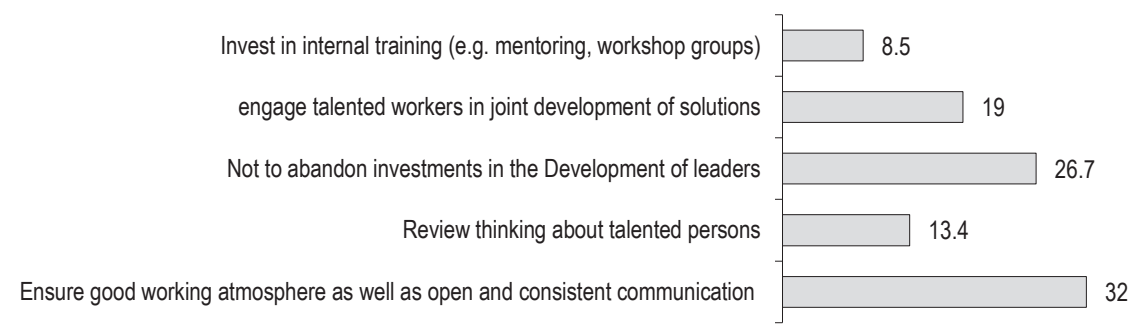

Figure 9 . Factors determining the functioning of "talent management" programs in the organization in the respondents' opinion (\%)

Source: own study.

Over $32 \%$ of respondents believe that a good working atmosphere, as well as open and consistent communication are among the factors determining the functioning of talent management programs. Maintaining a good working atmosphere, consistent and open communication is primarily a task for managers in the organization. They are the main creators of organizational culture. It should be remembered that good interpersonal relations with management and other co-workers not only positively affect motivation but can also compensate for other inconveniences in the company. Therefore, this type of support for talented employees is necessary, both on the part of superiors and other team members. Open and consistent communication positively influences building trust and loyalty in the team. Lack of a good atmosphere may lead to reluctance of the managers to talented people, lack of faith in their abilities and, finally, depreciate their value.

The next essential factor is not to abandon but take care of the development of leaders $(26.7 \%)$. The respondents appreciate the importance of teamwork and common values. In today's organization, leadership is teamwork of a competent manager targeted at achieving goals set by the organization. Both the leader and the team undertake activities that guarantee the achievement of the organization's success. It gives a sense of co-creation of the company. Noteworthy is also (as indicated by $19 \%$ of respondents) engaging talented workers in joint development of solutions. The development of talent is influenced by the tasks to be carried out, as well as events and completely accidental situations related to the performance of duties at the workplace. When trying to solve them, creativity and entrepreneurship of the talented is "freed". Owing to this, talented people are able to take risks while fulfilling tasks, and introduce new concepts or ideas.

It was found to be insignificant to review thinking about talents (13.4\%) and invest in internal training (8.5\%).

In the conducted research, the behaviors shaping the image of a talented employee were identified. The results are displayed in Figure 10. 


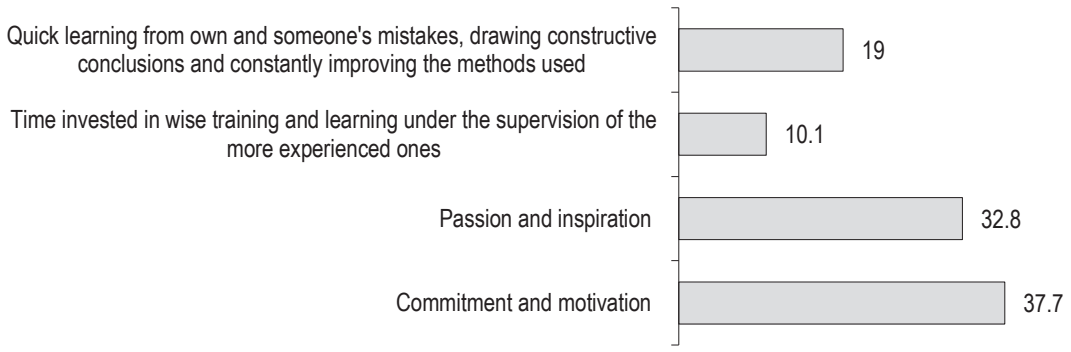

Figure 10. Opinions about behaviors that shape the image of an employee as a specialist/an expert (\%)

Source: own study.

Commitment and motivation are behaviors that characterize talented people $(37.7 \%)$. The respondents 'opinions are in line with some research findings regarding specialists and people of success, that we are not born with talent. People only have certain predispositions that facilitate the development of specific skills. Commitment, determination and dedication are necessary to reach a master level in them. It is a long-lasting process, lasting several or even tens of years.

According to $32.8 \%$ of respondents, passion and inspiration are important. Passion is defined as a strong fondness for something, while inspiration is afflation or eagerness for something. The meaning of these words results in freedom in action and in the inner need for self-fulfillment.

Quick learning from mistakes, drawing constructive conclusions and constantly improving the methods and strategies applied, testing and trial and error methods, as well as self-improvement are important behaviors in shaping talents for $19 \%$ of respondents.

The respondents do not attach importance to the time invested in wise training and learning, under the guidance of the more experienced persons (as indicated by 10.1\%). In organizations, too little importance is attached to training and professional development. Such undertakings must be usually covered out of employees' own financial resources.

\section{Conclusion}

The essence of implementing talent management programs is to gain a competitive advantage on the market and retaining talented people important to the organization. The functioning of such programs has a very positive impact on the image of the organization on the external labor market. This ensures the inflow of new, talented workers.

The employee's determination and individual desire to develop are usually sufficient to improve the potential. Commitment and motivation are behaviors that characterize talented people. The involvement of the managerial staff in the talent management process allows for much faster development of employee competencies. This is "acceleration" that is the desired effect of talent management programs.

Talent management is not just about identifying talented people by managers and directing them to various types of training or courses. The challenge is to use them efficiently and skillfully over their entire working lifetime. Therefore, talented people ought to receive a planned support and individual career paths (professional development). It is a task for managers at particular levels in the organizational structure and HR departments. Talent management 
programs should be "tailor-made". It must be borne in mind that employees only have certain predispositions that facilitate the development of specific skills. They should be aligned with current and future needs of the organization and meet expectations of the employee. In practice, this means additional training, workshops and coaching for the employee. A significant part of the respondents in the research confirmed the fact that the lack of opportunities for development or promotion is the reason for the fluctuation of talented people.

Companies do not care for a good working atmosphere or professional development of talented people. Organizations neither invest in the employees' development nor create opportunities for promotion and professional development. It should be remembered that the accumulated "intellectual capital" brings measurable results and benefits to the company. The underestimation of employees' values is evidenced by the fact that only two people were sent for studies by employers. Managers should be aware that a good working atmosphere and a friendly climate are conducive to improving efficiency. The lack of positive interpersonal relationships causes conflicts and demobilization for effective work. Undervaluation of talented people by superiors is the main reason for resignation from work.

Employees qualified for talent management programs should take into account additional work and increased work intensity. Superiors and co-workers' expectations towards them from are greater. Therefore, their actions are less permissible to make mistakes or possible failures.

Talent Management is the most effective way to retain talented people in the organization. Bearing in mind the increasing globalization and business cycles, organizations ought to develop talents using their potential during the crisis and prepare for the next stage of economic growth.

\section{References}

Antczak, Z. (2010). Rozwój pracowników. In: T. Listwan (ed.), Zarządzanie kadrami. Warszawa: C.H. Beck.

Borkowska, S. (2005). Zarządzanie talentami. Warszawa: Difin.

Chełpa, S. (2015). Samorealizacja talentów - możliwości i ograniczenia interpersonalne. In: S. Borkowska (ed.), Zarządzanie talentami. Warszawa: Difin.

Ingram, T. (2011). Zarządzanie talentami. Warszawa: PWE.

Jabłoński, M. (2015). Istota, funkcje i praktyki zarządzania talentami pracowniczymi. Zeszyty Naukowe Wyższej Szkoły Bankowej w Poznaniu, 60 (3), 31-48.

Listwan, T. (2005). Zarządzanie talentami - wyzwanie współczesnych organizacji. In: S. Borkowska (ed.), Zarządzanie talentami. Warszawa: IPiSS.

Pocztowski, A. (2008). Zarządzanie talentami w organizacji. Kraków: Oficyna Wolters Kluwer Business.

Cite this article aS: Balcerzyk, R., Balcerzyk, D. (2018). Managing talented employees. European Journal of Service Management, 3 (27/2), 17-26. DOI: 10.18276/ejsm.2018.27/2-02. 